\title{
Influence of steam heating on the properties of pine (Pinus pinaster) and eucalypt (Eucalyptus globulus) wood
}

Bruno Esteves1, António Velez Marques2, IdALina Domingos1 AND HELENA PEREIRA3

1Dep. Engenharia de Madeiras, Escola Superior de Tecnologia de Viseu, Instituto Politécnico de Viseu

2 Centro de Investigação em Engenharia Química e Biotecnologia, Instituto Superior de Engenharia de Lisboa

3Centro de Estudos Florestais, Instituto Superior de Agronomia, Universidade Técnica de Lisboa

Email: bruno@demad.estv.ipv.pt

Fax: 0351232424651

Phone: $0351-232480645$ or $0351-919056830$

\section{Acknowledgement}

The authors would like to thank Wood Science and Technology for this publication. The original publication is available at

http://www.springerlink.com/content/ym146014 $263 \mathrm{~m} 6413 /$

\section{Reference}

Esteves, B., Velez Marques, A., Domingos, I., Pereira, H 2007 Influence of steam heating on the properties of pine (Pinus pinaster) and eucalypt (Eucalyptus globulus) wood. Wood Science and Technology.41:193-207. DOI : 10.1007/s00226006-0099-0. 


\section{Abstract}

Heat treatment of Pinus pinaster and Eucalyptus globulus woods, two important species in Portugal, was made in the absence of air by steaming, inside an autoclave, for 2 to $12 \mathrm{~h}$ at $190{ }^{\circ} \mathrm{C}$ to $210^{\circ} \mathrm{C}$. Mass losses increased with treatment time and temperature reaching $7.3 \%$ for pine and $14.5 \%$ for eucalypt wood. The wood behaviour with moisture was improved. The equilibrium moisture content decreased by $46 \%$ for pine and $61 \%$ for eucalypt, the dimensional stability increased (maximum anti-shrinking efficiency in the radial direction of $57 \%$ and $90 \%$ for pine and eucalypt respectively) and the surface wettability was lowered. In relation to mechanical properties, the modulus of elasticity was little affected (maximum decrease of $5 \%$ for pine and $15 \%$ for eucalypt) but the bending strength was reduced (by $40 \%$ at $8 \%$ mass loss for pine and $50 \%$ at $9 \%$ mass loss for eucalypt wood).

The variation of properties was related to treatment intensity and mass loss but significant improvements could already be obtained for a 3-4\% mass loss without impairing the mechanical resistance. The response of eucalypt was higher than that of pinewood. Heat treatment of eucalypt wood shows an interesting potential to improve the wood quality for solid timber products.

\section{Introduction}

The first studies on heat treatment to improve dimensional stability of wood have been carried out by Stamm et al. (1946). Recently, environmental concerns and scarcity of high quality wood encouraged the search of new preservation methods without the use of harmful chemicals and heat treatment processes have evolved in some European countries. Thermowood in Finland (Viitanen et al. 1994), Plato Wood in Holland (Tjeerdsma et al. 1998), Rectification and Bois-Perdure in France (Dirol and Guyonnet 1993) and OHT in Germany (Rapp 2001) are different wood heat treatments that are in pilot plant or commercial phases.

Heat treatment reduces the equilibrium moisture content of wood (Jämsä and Viitaniemi 2001; Nakano and Miyazaki 2003; Gosselink et al. 2004;Wang and Cooper 2005; Metsä-Kortelainen et al. 2005) and improves its dimensional stability (Kollmann and Schneider 1963; Viitaniemi et al. 1997; Epmeier et al., 2001; Yildiz 2002; Bekhta and Niemz 2003; González-Peña et al. 2004; Wang and Cooper 2005) and rot resistance (Kim et al. 1998; Kamdem et al. 2002; Hakkou et al. 2006), thereby allowing treated wood to be used in less favourable 
conditions and to compete with tropical wood of higher cost. Heat treatment also darkens the wood (Mitsui et al. 2001; Bekhta and Niemz 2003) which is an advantage for light coloured woods which are usually less appealing to the consumer. The major disadvantage is the reduction of mechanical resistance (Kim et al. 1998, Kubojima et al. 2000; Bengtsson et al. 2002; Reiterer and Sinn 2002; Epmeier et al. 2004; Unsal and Ayrilmis 2005; Johansson and Morén 2006) that can be an impediment for some uses. Although wettability decreases (Pétrissans et al. 2003; Hakkou et al. 2005a.2005b) the gluing process can be adapted for treated wood (Militz 2002).

In the last few years research on the heat treatment of wood has been active namely regarding the understanding of the chemical changes in treated wood (Kotilainen et al. 2000; Zaman et al. 2000; ; Sivonen et al. 2002; Wikberg and Maunu 2004; Nuopponen et al 2004a. 2004b; Bhuiyan et al. 2005; Tjeerdsma and Militz 2005; Boonstra and Tjeerdsma 2005; Yamauchi et al. 2005; Reppellin and Guyonnet 2005) and the development of new test methods (Schwanninger et al. 2004; Rapp et al. 2006; Johansson and Morén 2006).

Pinus pinaster and Eucalyptus globulus are two of the forest species with most planted area in Portugal. Pine wood is used for all kinds of carpentry and furniture, although for outdoor use it must be treated since it is a low durable species. Until 2005 it was mainly treated with chromated copper arsenate (CCA) and currently with chromated copper borate (CCB).

The eucalypt wood is one of the less valued wood in the market for timber applications because it is considered to be non durable, with high dimensional instability and very difficult to treat, even under pressure. The impregnation is only possible for small diameters without heartwood and there is a considerable leaching of preservative solution because of the large diameter of vessels. However preserved eucalypt wood is still susceptible to soft-rot fungus attack (Reimão and Nunes 1989). Eucalypt wood is used almost exclusively for paper production but older eucalypts with very high extractives content that are not adequate for pulping are used as firewood or for less demanding pieces of furniture.

It is the objective of this paper to study the effect of steam heating of eucalypt and pine woods as a method to improve the wood technological quality as regards dimensional stability and durability. 


\section{Experimental}

\section{Material and heat treatment}

Pine (Pinus pinaster) and eucalypt (Eucalyptus globulus) wood came from the Portuguese region of Águeda. Cubic samples of approximately $40 \mathrm{~mm}$ edge were cut from a radial board with clear radial, tangential and transversal faces. Samples were kept in a conditioned room at $50 \%$ relative humidity and $20{ }^{\circ} \mathrm{C}$. After three weeks, mass and equilibrium moisture content of all the samples were determined. Treatments were made at atmospheric pressure inside an autoclave with $0.5 \mathrm{~m}^{3}$ capacity and $1.0 \mathrm{~m}^{2}$ square area for 2 to 12 hours and for $190{ }^{\circ} \mathrm{C}, 200{ }^{\circ} \mathrm{C}$ and $210^{\circ} \mathrm{C}$. Heating was performed by admission of steam into the autoclave. Steam temperature adjustment at the autoclave entrance was performed by previous mixing of superheated steam $\left(370-380{ }^{\circ} \mathrm{C}\right)$ and saturated steam $\left(150-160{ }^{\circ} \mathrm{C}\right)$. Admission of steam was not continuous. Auxiliary heating and temperature control was obtained by flow control of superheated steam in the autoclave's sleeve. After treatment the samples were cooled in a dry environment and weighted. Mass loss was determined in relation to dry wood.

\section{Wood properties}

Treated and untreated samples were kept in an oven at $20^{\circ} \mathrm{C}$ and $35 \%$ relative humidity. After stabilization, samples were weighted and measured in radial, tangential and transversal directions. This procedure was repeated for $65 \%$ and $85 \%$ relative humidity conditions. Dimensional stability was determined by the Anti Shrinking Efficiency (ASE) method used by Stamm (1946), which gives the shrinking difference between treated and untreated samples calculated in percent, and determined between air relative humidities of $35 \%, 65 \%$ and $85 \%$ and the dry state (respectively $\mathrm{ASE}_{35}, \mathrm{ASE}_{65}$ and $\mathrm{ASE}_{85}$ ). For example $\mathrm{ASE}_{35}$ (\%) $=\left(\frac{S_{n t}-S_{t}}{S_{n t}}\right) * 100$

where $S_{n t}$ and $S_{t}$ represent the shrinking between $35 \%$ relative humidity and $0 \%$ relative humidity for non treated (nt) and treated (t) samples. The shrinking is determined in percent as 
$\mathrm{S}(\%)=\left(\frac{L_{35 \%}-L_{0 \%}}{L_{35 \%}}\right) * 100$

with $\mathrm{L}$ representing the dimension of the sample.

ASE determinations were made in radial and tangential directions and total ASE corresponds to the volume.

Bending strength and modulus of elasticity were determined with 360x20x20 $\mathrm{mm}^{3}$ (axial $\mathrm{x}$ radial $\mathrm{x}$ tangential) samples and a three point bending device. Measurements were made using a constant velocity of $0.3 \mathrm{~mm} / \mathrm{min}$ for MOE and a velocity estimated to cause rupture in $3 \mathrm{~min}$ for bending strength. MOE and bending strength were determined according to:

$\operatorname{MOE}\left(\mathrm{N} / \mathrm{mm}^{2}\right)=\frac{\Delta F^{*} L^{3}}{\Delta x * 4 * b^{*} h^{3}}$ 619)

where $\mathrm{F}$ is the load on rupture in $\mathrm{N}, \frac{\Delta F}{\Delta x}$ is the slope of the elastic zone in $\mathrm{N} / \mathrm{mm}$, $\mathrm{L}$ is the arm length, $\mathrm{h}$ the height and $\mathrm{b}$ the width all expressed in $\mathrm{mm}$.

Wettability of wood was determined according to the contact angle method, measured 10 seconds after the contact of the drop with the wood measured in radial and tangential sections.

\section{Results and discussion}

\section{Mass loss}

Table 1 shows the mass loss of pine and eucalypt wood with the steam heat treatment. Mass loss of pine in the temperature range $190-210^{\circ} \mathrm{C}$ was between $0.4 \%$ and $7.3 \%$ while for eucalypt wood mass loss was between $3.7 \%$ and $14.5 \%$. Mass loss increased with time and temperature of treatment for both wood species but they differed in magnitude and kinetics of the thermal induced mass loss. For the same temperature and treatment time, the mass loss of eucalypt wood was much higher than that of pine wood, i.e. $12.1 \%$ vs. $4.4 \%$ at $200^{\circ} \mathrm{C}$ and 
12h. The difference was more striking with short treatment durations and lower temperatures (i.e. $5.4 \%$ vs. $0.4 \%$ with $2 \mathrm{~h}$ at $190^{\circ} \mathrm{C}$ ).

The higher degradation of eucalypt wood can partially be explained by the difference in chemical composition, namely in relation to the hemicellulosic fraction which is less resistant to thermal degradation than lignin (Zaman et al. 2000). Eucalypt wood has on average $54.0 \%$ cellulose, $23.1 \%$ lignin and $18.9 \%$ hemicelluloses (Pereira 1988) or $51.3 \%$ cellulose, $21.9 \%$ lignin and $21.3 \%$ hemicelluloses (Patt et al. 2006). In some analysis with FTIR techniques cellulose varied between 43.2-59.5\% (Rodrigues et al. 2001) and lignin between 23-34\% (Rodrigues et al. 1997). Pine wood has about $57.4 \%$ cellulose, $28.6 \%$ lignin and $10.7 \%$ hemicelluloses (Carvalho 1960) or according to FTIR determinations 46.4\% alpha cellulose, 29.0\% lignin and 24.2\% hemicelluloses (Pot et al. 2002). The lignin content differs between sapwood and heartwood with respectively $26.7 \%$ and $28.7 \%$ (Esteves et al. 2005). Additional differences relate to the composition of hemicelluloses, since hardwood xylans have a higher susceptibility to thermal degradation than softwood mannans (Alén et al. 1995).

Moreover, pine and eucalypt lignins have a different monomeric composition: in pine the H/G. (hydroxyphenol/guaiacyl) ratio is 0.06 (Alves et al. 2006) and the methoxyl content $13.1 \%$ (Vasquez et al. 1997), while in eucalypt the S/G (syringyl/guaiacyl) ratio is 2.0 (Rodrigues et al. 1999) and the methoxyl content is $17.3 \%$ (Vasquez et al. 1997). The higher methoxyl content of eucalypt lignin inhibits $\mathrm{C}-\mathrm{C}$ ring condensations reducing the thermal stability of lignin (Kosikova et al. 1993) and leading to a higher release of units during heat treatment.

\begin{tabular}{ccccc}
\hline Wood & Treatment & \multicolumn{3}{c}{ Mass loss $(\%)$} \\
& Time $(\mathrm{h})$ & $190{ }^{\circ} \mathrm{C}$ & $200^{\circ} \mathrm{C}$ & $210^{\circ} \mathrm{C}$ \\
\hline \multirow{3}{*}{ Pine } & 2 & 0.4 & 2.1 & 4.4 \\
& 6 & 3.5 & 3.5 & 6.8 \\
& 12 & 3.7 & 4.4 & 7.3 \\
\hline \multirow{3}{*}{ Eucalypt } & 2 & 5.4 & 3.7 & 10.4 \\
& 6 & 7.6 & 10.2 & 13.9 \\
& 12 & 8.7 & 12.1 & 14.5 \\
\hline
\end{tabular}

Table1. Mass loss (in \% of initial o.d. mass) of pine and eucalypt wood during steam heat treatment with different temperatures. 
The mass losses found here for the heat treated pine wood at $210^{\circ} \mathrm{C}$ are not much different from those observed by Zaman et al. (2000) for Pinus sylvestris with $5.7 \%, 6.8 \%$ and $7.0 \%$ of mass losses for wood treatments at $205^{\circ}$ for 4,6 and 8 hours.

Eucalypt wood has not been investigated in relation to heat treatments and therefore no information is available in the literature regarding its thermal degradation. Zaman et al. (2000) reported mass losses of $6.4 \%, 7.1 \%$ and $10.2 \%$ for Betula pendula treated at $205^{\circ}$ for 4,6 and 8 hours. These mass losses are lower than those obtained for eucalypt.

In general, mass loss increased with time and temperature of treatment which is in agreement with earlier reported data for Scots pine and silver birch (Zaman et al. 2000) and spruce (Alén et al. 2002).

\section{Equilibrium moisture content}

The equilibrium moisture content of untreated wood at 35\%,65\% and $85 \%$ relative humidity was $8.3 \%, 12.6 \%$ and $18.4 \%$ for pine wood and $7.1 \%, 10.5 \%$ and $14.4 \%$ for eucalypt wood.
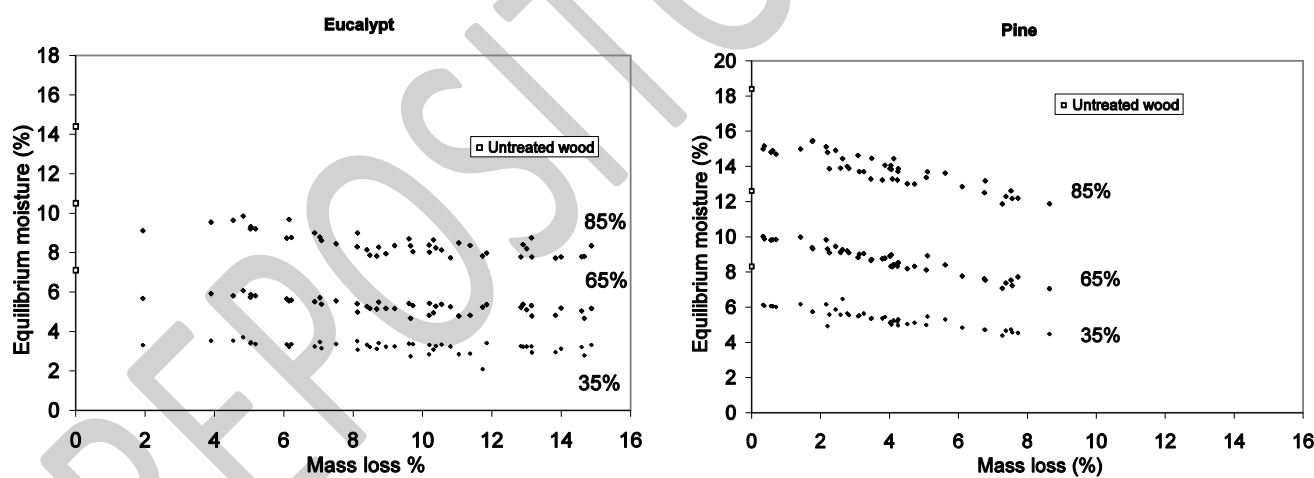

Fig.1. Equilibrium moisture content vs. mass loss for heat treated pine and eucalypt wood for $35 \%, 65 \%$ and $85 \%$ air relative humidity.

The equilibrium moisture content of all heat treated samples decreased in relation to the initial untreated wood, even for the less intensive 2 -hour treatment at $190^{\circ} \mathrm{C}$. The reduction in the equilibrium moisture content was related to the mass loss that occurred with the treatment (Fig. 1). It was slightly higher until 6-8\% mass loss, especially for eucalypt wood, remaining approximately constant for higher mass losses. Similar results were obtained by Viitaniemi et al. (1997) with spruce wood, who reported that the maximum reduction in the wood equilibrium moisture content was reached at $6 \%$ mass loss. 
The equilibrium moisture content decreased with treatment temperature reaching $5.4 \%$ and $3.1 \%$ at $190{ }^{\circ} \mathrm{C}$ and $4.5 \%$ and $2.8 \%$ at $210{ }^{\circ} \mathrm{C}$ for pine and eucalypt wood, respectively.

The difference in percentage between untreated and treated samples narrowed with increasing air relative humidity despite the smaller absolute values at $35 \%$ relative humidity. The decrease of equilibrium moisture was smaller for $65 \%$ and $85 \%$ air relative humidity when compared with the $35 \%$ air relative humidity, e.g. at $85 \%$ relative humidity the maximum decrease was $46 \%$ and $35 \%$ of the initial equilibrium moisture content for eucalypt and pine wood respectively and at $35 \%$ relative humidity the reduction was $61 \%$ and $46 \%$ respectively. These results are in agreement with earlier data obtained by Kamdem et al. (2002) for beech wood treated at temperatures between $200-260^{\circ} \mathrm{C}$. The moisture content of beech wood decreased $50 \%$ and $45 \%$ for $66 \%$ and $86 \%$ relative humidity.

At the same temperature and time of treatment, the decrease was higher for eucalypt wood. For instance in $210^{\circ} \mathrm{C}$-treated samples conditioned at $35 \%$ air relative humidity, the equilibrium moisture content was $2.8 \%$ for eucalypt wood, and $4.5 \%$ for pine wood. For the same mass loss, the equilibrium moisture of eucalypt wood was also lower than that of pine wood for all the three tested air relative humidities (Fig. 1). The difference between the equilibrium moisture content reached at the three air relative humidities was also smaller for eucalypt wood.

\section{Dimensional stability}

The dimensional stability of pine and eucalypt wood was improved by the heat treatment in all the cases. The increase in dimensional stability, as measured by the anti-shrinking efficiency (ASE), was higher in the tangential than in the radial direction but the differences were small (Table 2). The total volumetric ASE had intermediate values between radial and tangential ASE, since there was almost no difference in the axial direction. Similar results were obtained by Tjeerdsma et al. (1998) with beech, spruce, Scots pine and Monterey pine. 


\begin{tabular}{|c|c|c|c|c|c|c|c|}
\hline \multirow{2}{*}{$\begin{array}{c}\text { Temp. } \\
{ }^{\circ} \mathrm{C}\end{array}$} & \multirow{2}{*}{$\begin{array}{c}\text { Time } \\
\text { (h) }\end{array}$} & \multicolumn{3}{|c|}{ Pine } & \multicolumn{3}{|c|}{ Eucalypt } \\
\hline & & Radial & Tangential & Total & Radial & Tangential & Total \\
\hline \multirow[t]{3}{*}{190} & 2 & 39.4 & 39.3 & 40.1 & 80.6 & 69.7 & 75.2 \\
\hline & 6 & 26.6 & 50.6 & 43.4 & 89.8 & 73.1 & 78.6 \\
\hline & 12 & 38.8 & 56.1 & 48.2 & 77.2 & 82.4 & 80.3 \\
\hline \multirow[t]{3}{*}{200} & 2 & 30.9 & 42.9 & 35.9 & 72.8 & 76.2 & 66.8 \\
\hline & 6 & 43.8 & 52.5 & 50.5 & 69.4 & 75.4 & 73.9 \\
\hline & 12 & 38.6 & 47.6 & 44.9 & 61.4 & 76.4 & 67.0 \\
\hline \multirow[t]{3}{*}{210} & 2 & 35.7 & 53.3 & 41.7 & 77.7 & 80.8 & 79.0 \\
\hline & 6 & 40.9 & 62.9 & 53.4 & 59.3 & 78.3 & 73.5 \\
\hline & 12 & 56.8 & 57.5 & 51.2 & 69.2 & 76.9 & 72.2 \\
\hline
\end{tabular}

Table 2. ASE at 35\% air relative humidity for the heat treatment of pine and eucalypt wood at temperatures $190-210^{\circ} \mathrm{C}$

The maximum $\mathrm{ASE}_{35}$ values in the radial direction that could be attained were between $40-57 \%$ for pine wood and $73-90 \%$ for eucalypt wood treated at 190$210^{\circ} \mathrm{C}$ (Table 2$)$.

The dimensional stability of the heat treated samples was higher in environments with lower relative humidity, e.g. $\mathrm{ASE}_{35}$ was higher than $\mathrm{ASE}_{65}$ and $\mathrm{ASE}_{85}$. Maximum values for radial $\mathrm{ASE}_{65}$ were between $34-49 \%$ for pine wood, and 67$72 \%$ for eucalypt wood and for $\mathrm{ASE}_{85}$ were $27-38 \%$ for pine wood and 54-62\% for eucalypt wood treated at temperatures between $190-210^{\circ} \mathrm{C}$.

The dimensional stability improvement was higher for eucalypt wood than for pine wood treated at the same time and temperature. For instance for wood treated during 6 hours at $200{ }^{\circ} \mathrm{C}, \mathrm{ASE}_{35}$ in radial direction increased about $44 \%$ for pine and $69 \%$ for eucalypt wood. Although untreated eucalypt samples had higher dimensional variation than pine $(3.4 \%$ and $2.4 \%$ respectively in tangential direction between $0 \%$ and $35 \%$ relative humidity), the treated eucalypt samples showed smaller dimensional variations $(0.8 \%$ and $1.1 \%$ for wood treated at $210^{\circ} \mathrm{C}$ during 12 hours). Comparing dimensional variation of treated and untreated pine and eucalypt wood with other species shows that chestnut has a dimensional variation of $1.7 \%$ in the tangential direction between $0 \%$ and $35 \%$ relative humidity (Ridjsdijk and Laming 1994), a value smaller than the untreated woods but higher than the heat treated samples. 
The ASE increased with mass loss during the heat treatment. For the same mass loss the tangential ASE increased slightly more than the radial ASE for heat treated pine and eucalypt wood (Fig. 2). The increase in ASE was higher for 35\% air relative humidity, and decreased for $65 \%$ and $85 \%$ relative humidity (Fig 3).

The rate of ASE increase seemed higher for mass losses until 6-8\%, remaining approximately constant for higher mass losses. However it is difficult to define a general trend since mass loss was lower than $8 \%$ for pine wood and generally higher than $6 \%$ for eucalypt making. Viitaniemi et al. (1997) reported similar results regarding ASE variation with mass loss for spruce wood.

At the same mass loss, ASE values were better for eucalypt wood than for pine. The maximum stability was obtained with 6-8\% mass loss which corresponds to the mass loss at which the minimum equilibrium moisture content was obtained. As for untreated wood there is a close relation between equilibrium moisture content and dimensional stability. Swelling decreases almost linearly (until near the fibre saturation point) with the equilibrium moisture content (Tsoumis 1991).
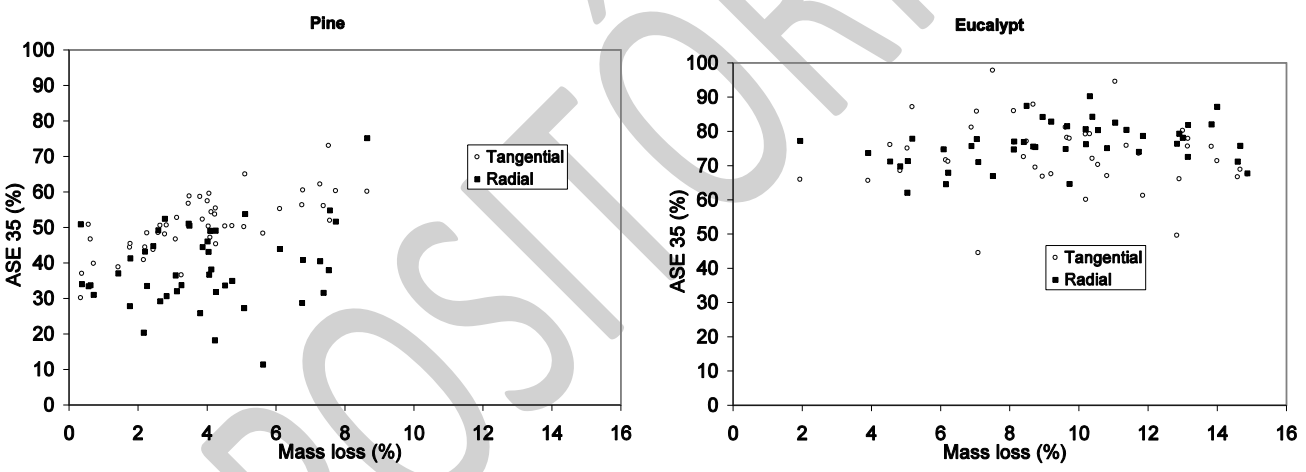

Fig. 2. Variation of $A_{S E} E_{35}$ in the radial and tangential directions with mass loss for heat treated pine and eucalypt wood.
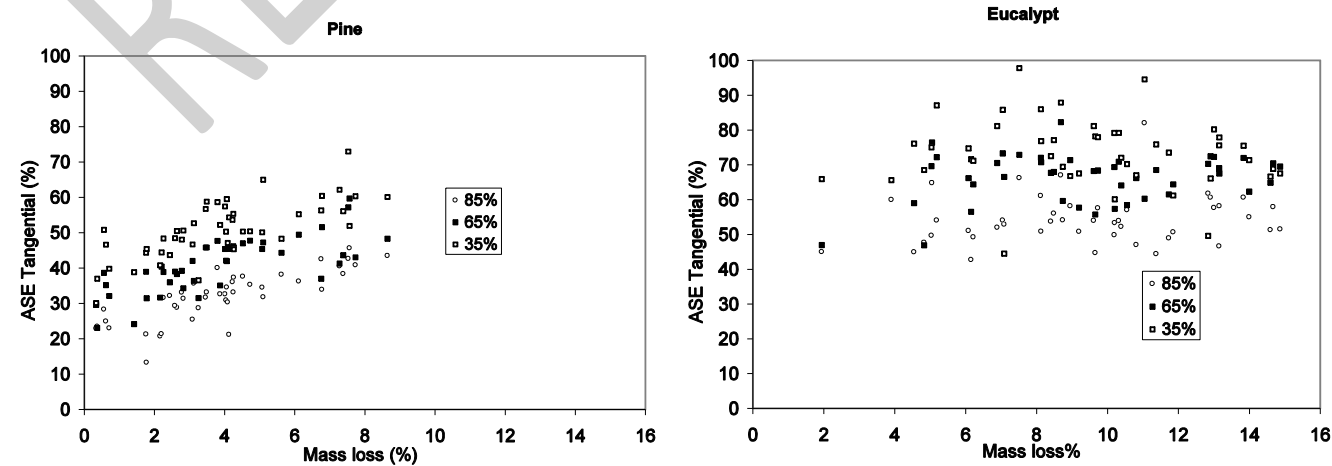

Fig. 3. Variation of tangential ASE with mass loss for heat treated pine and eucalypt wood for different air relative humidities. 


\section{Mechanical resistance}

The variation of mechanical properties of eucalypt and pine wood with the heat treatment is shown in Fig. 4 and 5, respectively for the modulus of elasticity (MOE) and the bending strength in function of the mass loss. MOE was less affected by the heat treatment than bending strength which is in agreement with Bengtsson et al. (2002).

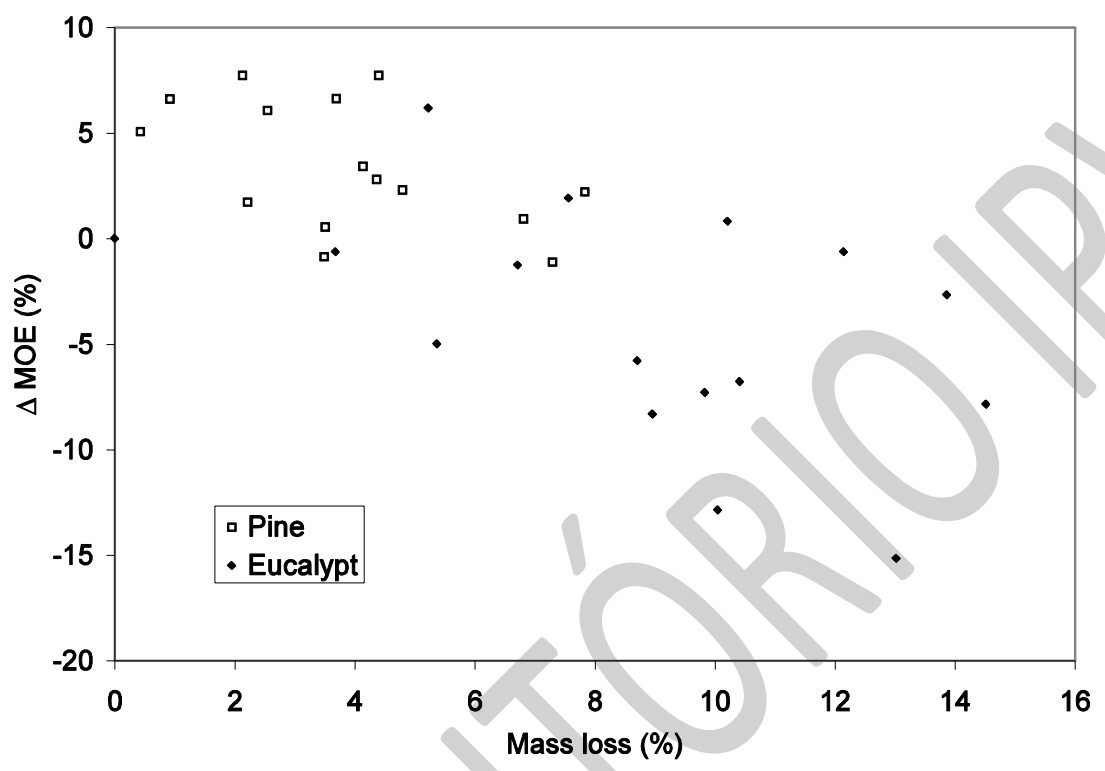

Fig. 4. Variation of MOE with mass loss for heat treated pine and eucalypt wood

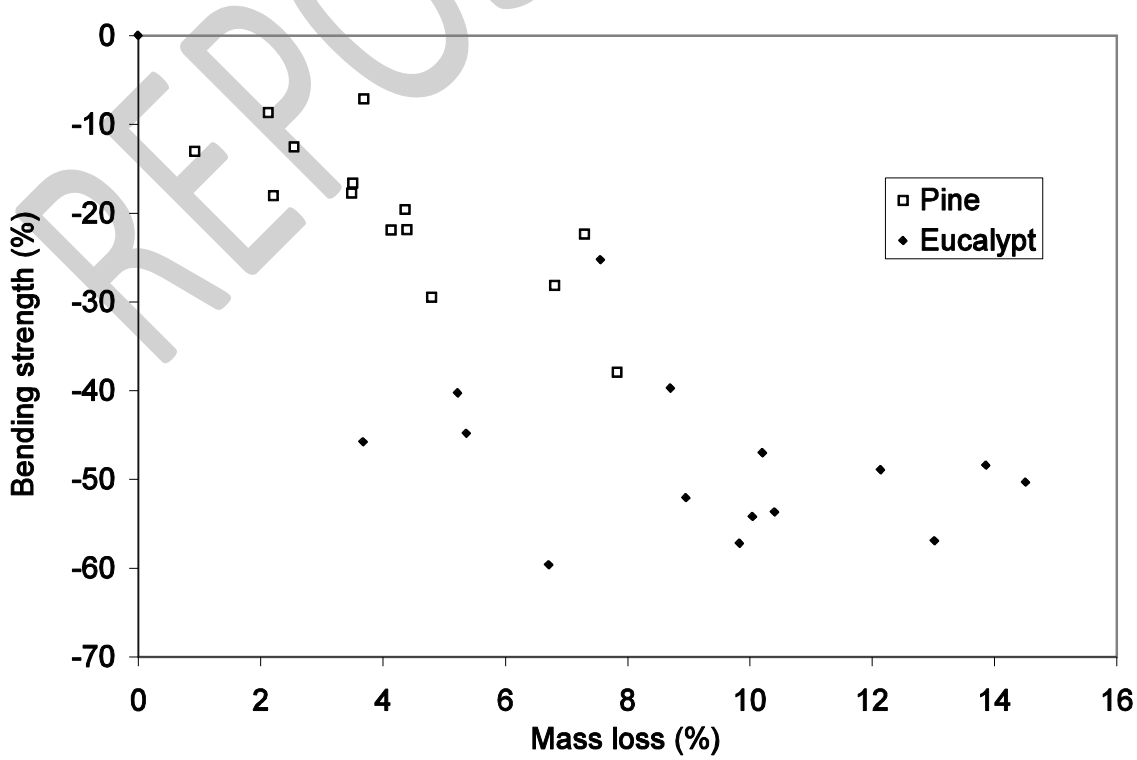

Fig. 5. Variation of bending strength with mass loss for heat treated pine and eucalypt wood 
The variation of modulus of elasticity was of small magnitude. In the case of heattreated pine wood it increased about $7 \%$ for mass losses until $4 \%$ and decreased afterwards for higher mass losses ( $2 \%$ of initial MOE for $8 \%$ mass loss). For eucalypt wood MOE decreased with mass loss, only slightly until $8 \%$ mass loss (about $5 \%$ of initial MOE) but about $15 \%$ for a $13 \%$ mass loss. The behaviour of MOE variation of heat-treated pine and eucalypt wood seemed similar at the same mass loss.

Vital et al. (1983) using Eucalyptus saligna wood treated at $105-155^{\circ} \mathrm{C}$ during $10-$ 160 hours obtained a similar decrease of MOE, but Santos (2000) reported an increase using Eucalyptus globulus.

Bending strength of heat-treated eucalypt and pine wood was smaller than the untreated wood and on average decreased with mass loss although a large between sample variability was found. For heat-treated pine wood the bending strength seemed to decrease at a constant rate: for mass losses under $2 \%$, bending strength decreased about $15 \%$ and for a mass loss of approximately $8 \%$ it attained a $40 \%$ decrease in relation to the initial value. Viitaniemi et al. (1997) reported a similar behaviour for spruce wood but with smaller values $(16 \%$ reduction at $8 \%$ mass loss).

The bending strength of heat-treated eucalypt wood seemed to decrease at a higher rate until 10\% mass loss, remaining approximately constant for higher mass losses (until 14\% mass loss). The decrease in bending strength for eucalypt wood was about $35 \%$ for $6 \%$ mass loss and reached $50 \%$ for $9 \%$ mass loss (Fig. 5). Bengtsson et al. (2002) obtained a similar reduction in bending strength of $50 \%$ for spruce wood and $47 \%$ for Scots pine wood treated at $220{ }^{\circ} \mathrm{C}$. However it should be noticed that there was a high between sample variation for similar mass losses: for instance, for $6-8 \%$ mass losses the bending strength of individual samples decreased from $20 \%$ to $65 \%$. The reduction on bending strength is the result of the chemical changes induced by the heat treatment that, as previously discussed, are of higher magnitude in eucalypt wood than in pine wood. Also a direct correlation between MOE and bending strength is affected in heat treated wood due to the selective chemical changes occurring in the wood structural components (with cellulose being preserved). 


\section{Wettability}

The contact angle of water on the heat-treated pine and eucalypt wood surfaces increased until about $1 \%$ mass loss, corresponding to a decrease in wood wettability (Fig. 6). No significant differences were found between the radial and tangential sections of measurement in the heat treated samples.

For the heat-treated pine wood the radial contact angle increased from $40^{\circ}$ to about $80^{\circ}$ for a $2.5 \%$ mass loss and decreased slightly afterwards to $60^{\circ}$ at $7 \%$ mass loss. For eucalypt wood the contact angle increased until $8 \%$ mass loss, remaining approximately constant afterwards at $75-80^{\circ}$ until $13 \%$ mass loss.

This increase in contact angle and consequent decrease in wettability with heat treatment is in agreement with earlier data (Pecina and Paprzycki 1988; Pétrissans et al. 2003; Hakkou et al. 2005a).
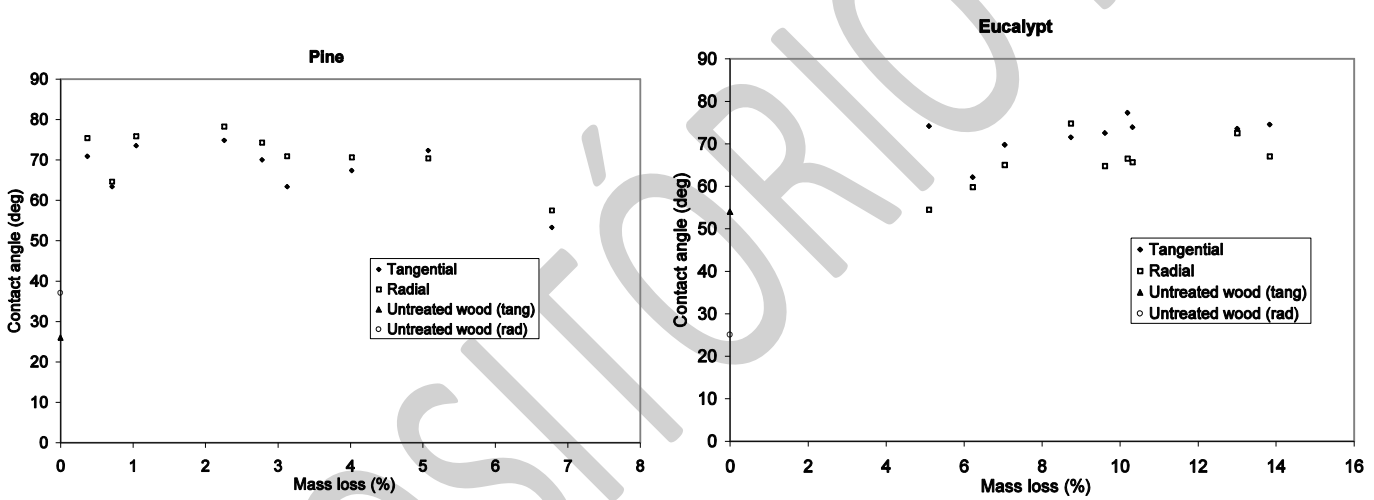

Fig. 6. Contact angle of pine and eucalypt treated wood vs. mass loss in tangential and radial sections.

\section{CONCLUSIONS}

The heat treatment of eucalypt and pine wood in an autoclave using superheated steam at $190^{\circ} \mathrm{C}-210^{\circ} \mathrm{C}$ allowed to improve the wood behaviour in relation with moisture by decreasing the wood equilibrium moisture content, increasing its dimensional stability and lowering the surface wettability. In relation to mechanical properties, the modulus of elasticity was little affected but the bending resistance was reduced.

The variation of properties was related to the intensity of the heat treatment and the corresponding mass loss but significant improvements could already be obtained for a mass loss of 3-4\% without impairing the mechanical resistance. 
The response of eucalypt to the heat treatment was higher than that of pinewood both regarding mass and improvement of properties. Heat treatment of eucalypt wood shows an interesting potential to improve the wood quality for solid timber products.

\section{REFERENCES}

Alén R, Kotilainen R, Zaman A (2002) Thermochemical behaviour of Norway spruce (Picea abies) at 180$225{ }^{\circ} \mathrm{C}$ Wood Sci. and Technol. 36:163-171

Alén R, Oesch P, Kuoppala E (1995) Py-GC/AED studies on thermochemical behaviour of softwood. J Anal Appl Pyrolysis 35: 259-265

Alves A, Schwanninger M, Pereira H, Rodrigues J (2006) Calibration of NIR to assess lignin composition (H/G ratio) in maritime pine wood using analytical pyrolysis as the reference method. Holzforschung 60:2931

Bekhta P, Niemz P (2003) Effect of high temperature on the change in colour, dimensional stability and mechanical properties of spruce wood. Holzforschung 57: 539-546

Bengtsson C, Jermer J, Brem F (2002) Bending strength of heat-treated spruce and pine timber. Int Res Group Wood Pre, Section 4-Processes, N IRG/WP 02-40242

Bhuiyan T, Hirai N (2005) Study of crystalline behaviour of heat-treated wood cellulose during treatments in water. J Wood Sci 51: 42-47.

Boonstra M, Tjeerdsma B (2006) Chemical analysis of heat treated softwoods. Holz Roh-Werkst, Online first, DOI: 10.1007/s00107-005-0078-4

Carvalho A (1960) Alguns inconvenientes do azulamento na madeira de P. Pinaster com vista ao seu aproveitamento em pasta para papel, Separata das publicações da Direcção Geral dos Serviços Florestais e Aquicolas 27.

Dirol D, Guyonnet R (1993) Durability by rectification process. Int Res Group Wood Pre, Section 4Processes, No IRG/WP 93-40015

Epmeier H, Bengtsson C, Westin M (2001) Effect of acetylation and heat treatment on dimensional stability and MOE of spruce timber, In: Proceedings for the first conference of the European society for wood mechanics Abril 19-21 2001, Lausanne, Switzerland.

Epmeier H, Westin M, Rapp A (2004) Differently modified wood: comparison of some selected properties Scand. J For Res 19: 31-37

Esteves B, Gominho J, Rodrigues J, Miranda I, Pereira H (2005) Pulping yield and delignification kinetics of heartwood and sapwood of Maritime pine. J Wood Chem Technol 25:217-230.

González-Peña M, Breese M, Hill C (2004) Hygroscopicity in Heat-Treated Wood: Effect of extractives ICECFOP - International Conference on Environmentally Compatible Forest Products. 22-24 September 2004. pp. 105-119.

Gosselink R, Krosse A, Van der Putten J, Van der Kolk J, Klerk-Engels B, Dam J (2004) Wood preservation by low-temperature carbonisation, Ind Crops Prod 19: 3-12.

Hakkou M, Pétrissans M, Zoulalian A, Gérardin P (2005a) Investigation of wood wettability changes during heat treatment on the basis of chemical analysis. Polym Degrad Stab 89: 1-5

Hakkou M, Pétrissans M, EI Bakali I, Gérardin P, Zoulalian A (2005b) Wettability changes and mass loss during heat treatment of wood. Holzforschung, 59: 35-37 
Hakkou M, Pétrissans M, Gérardin P, Zoulalian A (2006) Investigation of the reasons for fungal durability of heat-treated beech wood. Polym Degrad Stab 91: 393-397

Jämsä S, Viitaniemi P (2001) Heat treatment of wood - Better durability without chemicals. Proceedings of special seminar held in Antibes, France

Johansson D, Morén T (2006) The potential of colour measurement for strength prediction of thermally treated wood. Holz Roh-Werkst 64: 104-110

Kamdem D, Pizzi A, Jermannaud A (2002) Durability of heat treated wood. Holz Roh-Werkst 60: 1-6

Kim G, Yun K, Kim J (1998) Effect of heat treatment on the decay resistance and the bending properties of radiata pine sapwood. Material und Organismen 32 (2): 101-108

Kollmann F, Schneider A (1963) On the sorption behaviour of heat stabilized wood. Holz Roh-Werkst 21 (3): $77-85$

Kosikova B, Ebringerova A, Kacurakova M (1993) Structural changes of spruce wood ligninpolysaccharide complex upon steaming. Drevarsky Vyskum, 38(2): 1-9.

Kotilainen R, Toivannen T, Alén R (2000) FTIR monitoring of chemical changes in softwood during heating. J Wood Chem Technol 20 (3): 307-320.

Kubojima Y, Okano T, Ohta M (2000) Bending strength of heat-treated wood. Journal of Wood Science 46: $8-15$

Metsä-Kortelainen S, Antikainen T, Viitaniemi P (2006) The water absorption of sapwood and heartwood of Scots pine and Norway spruce heat-treated at $170^{\circ} \mathrm{C}, 190^{\circ} \mathrm{C}, 210^{\circ} \mathrm{C}$ and $230^{\circ} \mathrm{C}$. Holz Roh-Werkst, Online first. DOI: 10.1007/s00107-005-0063-y

Militz H (2002) Thermal treatment of wood: European Processes and their background. Int Res Group Wood Pre, Section 4-Processes, No IRG/WP 02-40241

Mitsui K, Takada H, Sugiyama M, Hasegawa R (2001) Changes in the properties of light-irradiated wood with heat treatment: Part 1 Effect of treatment conditions on the change in colour. Holzforschung, 55: 601605

Nakano T, Miyazaki J. (2003) Surface fractal dimensionality and hygroscopicity for heated wood, Holzforschung 57: 289-294.

NP 619 (1973)- Ensaio de flexão estática de madeiras

Nuopponen M, Vuorinen T, Jamsä S, Viitaniemi P (2004a) Thermal Modifications in Softwood Studied by FT-IR and UV Resonance Raman Spectroscopies. J Wood Chem Technol, 24: 13-26

Nuopponen M, Wikberg H, Vuorinen T, Maunu S, Jamsä S, Viitaniemi P (2004b) Heat-treated softwood exposed to weathering. J. Appl. Polym. Sci, 91: 2128-2134

Patt R, Kordsachia O, Fehr J (2006) European hardwoods versus Eucalyptus globulus as a raw material for pulping. Wood Sci Technol, 40: 39-48

Pecina H, Paprzycki O (1988) Wechselbeziehungen zwischen der temperaturbehandlung des holzes und seiner benetzbarkeit. Holzforschung und Holzverwertung 40(1): 5-8

Pereira H (1988) Variability in the chemical composition of plantation eucalypts (Eucalyptus globulus Labill). Wood Fib Sci 20 (1): 82-90

Pétrissans M, Philippe G, El Bakali I, Serraj M (2003) Wettability of heat-treated Wood. Holzforschung 57: $301-307$

Pincelli A, Brito J, Corrente J (2002) Avaliação da termorretificação sobre a colagem na madeira de Eucalyptus saligna e Pinus caribaea. Sci Forest 61: 122-132

Pot D, Chantre G, Rozenberg P, Rodrigues J, Jones G, Pereira H, Hannrup B, Cahalan C, Plomion C (2002) Genetic control of pulp and timber properties in maritime pine (Pinus pinaster Ait.) Ann. For. Sci., 59: 563-575 
Rapp A (2001) Review on heat treatments of wood, COST ACTION E22-Environmental optimisation of wood protection. Proceedings of Special Seminar in Antibes, France.

Rapp A , Brischke C, Welzbacher C (2006) Interrelationship between the severity of heat treatments and sieve fractions after impact ball milling: a mechanical test for quality control of thermally modified wood. Holzforschung, 60: 64-70

Reimão D, Nunes L (1989) Um estudo sobre a impregnabilidade de madeiras redondas de eucalipto comum. Lab Nacional de Engenharia Civil

Reiterer A, Sinn G (2002) Fracture behaviour of modified spruce wood: a study using linear and non linear fracture mechanics. Holzforschung 56: 191-198.

Repellin V, Guyonnet R. (2005) Evaluation of Heat Treated wood swelling by differential scanning calorimetry in relation to chemical composition. Holzforschung, 59: 28-34

Rijsdijk J, Laming P (1994) Physical and related properties of 145 timbers. Kluwer Academic Publishers, $380 \mathrm{pp}$

Rodrigues J, Meier D, Faix O, Pereira H (1999) Determination of tree to tree variation in syringyl/guaiacyl ratio of Eucalyptus globulus wood lignin by analytical pyrolysis. J Anal Appl Pyrolysis 48:121-128

Rodrigues J, Faix O, Pereira H (1998) Determination of lignin content of Eucalyptus globulus wood using FTIR spectroscopy. Holzforschung 52: 46-50.

Rodrigues J, Puls J, Faix O, Pereira H (2001) Determination of Monosaccharide Composition of Eucalyptus globulus wood by FTIR spectroscopy. Holzforschung 55: 265-269.

Santos J (2000) Mechanical behaviour of Eucalyptus wood modified by heat. Wood Sci.Technol 34: 39-43

Schwanningrer M, Hinterstoisser B, Gierlinger N, Wimmer R, Hanger J (2004) Application of Fourier Transform Near Infrared Spectroscopy (FT-NIR) to thermally modified wood. Holz Roh-Werkst, 62 (6): 483 485

Sivonen H, Maunu S, Sundholm F, Jämsa S, Viitaniemi P (2002) Magnetic Resonance Studies of Thermally Modified Wood. Holzforschung 56:648-654

Stamm A, Burr H, Kline A (1946) Stayb-wood-A heat stabilized wood, Ind. Eng Chem 38 (6): 630-634

Tjeerdsma B, Boonstra M, Pizzi A, Tekely P, Militz H (1998) Characterisation of thermally modified wood: molecular reasons for wood performance improvement. Holz Roh-Werkst 56: 149-153

Tjeerdsma B, Militz H. (2005) Chemical changes in hydrothermal wood: FTIR analysis of combined hydrothermal and dry heat-treated wood. Holz Roh-Werkst , 63: 102-11

Tsoumis G (1991) Science and technology of wood: Structure, properties, utilization. Chapman \& Hall

Unsal O, Ayrilmis N (2005) Variations in compression strength and surface roughness of heat-treated Turkish river red gum. Holz Roh-Werkst 51:405-409.

Vázquez G, Antorrena G, González J, Freire S (1997) FTIR 1H and 13C NMR Characterization of Acetosolv-Solubilized Pine and Eucalyptus Lignins. Holzforschung 51: 158-166.

Viitanen H, Jämsä S, Paajanen L, Nurmi A, Viitaniemi P, (1994) The effect of heat treatment on the properties of spruce IRG/WP 94-40032, 4p

Viitaniemi P, Jämsä S, Viitanen H (1997) Method for improving biodegradation resistance and dimensional stability of cellulosic products. United States Patent No 5678324 (US005678324)

Vital B, Lucia R, Della R, Euclides R (1983) Effect of heating on some properties of Eucalyptus saligna wood. Revista-Árvore 7 (2): 136-146

Wang J, Cooper P (2005) Effect of oil type, temperature and time on moisture properties of hot oil-treated wood. Holz Roh-Werkst 63, 417-422

Wikberg H, Maunu S (2004) Characterisation of thermally modified hard- and softwoods by 13C CPMAS NMR. Carbohydrate Polymers 58: 461-466. 
Yamauchi S, Iijima Y, Shuichi D (2005) Spectrochemical characterization by FT-Raman spectroscopy of wood Heat-treated at low temperatures:Japanese larch and beech. J Wood Sci 51: 498-506

Yildiz S (2002) Effects of heat tratment on water repellence and anti-swelling efficiency of beech wood Int Res Group Wood Pre, Section 4-Processes, No IRG/WP 02-40223.

Zaman A, Alen R, Kotilainen R (2000) Thermal behavior of Pinus sylvestris and Betula pendula at 200$230^{\circ} \mathrm{C}$. Wood Fib Sci 32(2): 138-143 